\title{
Taxonomic and Bio-geographical Studies of Three Bombus Species (Hymenoptera: Bombus) from North-West Himalaya with New Record from Trans Himalaya
}

Priyanka Kumari ${ }^{1}$, Avtar K. Sidhu $^{2}$

10.18805/IJAR.B-4549

\begin{abstract}
Background: Bumble bees play a crucial role in pollination of North West Himalayas. Bumble bees successfully thrive in the harsh environmental conditions of Himalayas. The present study aimed at taxonomic and zoogeographic studies of Bumble bees belonging to genus Bombus along with altitudinal variation of one species leading to its new record.

Methods: The collections surveys were conducted from the year 2017 to 2019 from altitude of 1000 to 3500 meters above sea level in North-West Himalaya. A total of 43 specimens belonging to three species were collected. These specimens were preserved as per standard techniques in Hymenoptera and identified following keys of eminent workers.

Result: The detailed taxonomy of three species of Bumble bees from North West Himalaya i.e., Bombus trifasciatus Smith, Bombus tunicatus Smith and Bombus simillimus Smith has been studied. The important taxonomic characters of different castes of these bee species have been elaborated and illustrations of morphological characters (including genitalia and sterna of male) of different castes i.e. queen, worker and male for each species are provided. The general foraging behaviour and altitudinal distribution along with floral preferences has been discussed in all the three species. The list of nectar food plants is provided under each species. B. trifasciatus has been recorded for the first time from Phey in cold desert in UT of Ladakh, which is being reported as new record in the Trans Himalayan region.
\end{abstract}

Key words: Collections, Floral preferences, Genitalia, Morphology, Taxonomy.

\section{INTRODUCTION}

Two union territories i.e. Jammu and Kashmir and Ladakh, and the state of Himachal Pradesh constitutes North West Himalaya of India. This area despite having harsh climatic conditions has diverse vegetation ranging from tropical to temperate flora. The reason behind this is the varying altitude which ranging between $100 \mathrm{mts}$ to $4000 \mathrm{mts}$ above sea level. Bumble bees play a crucial role in pollination of flowers of North West Himalaya. According to Williams (1991) bumble bees are the most ardent and successful visitors of flora in alpine, temperate environments of Himalaya. Their high relief provide a varied range of habitats for bumble bees. Bumble bees belong to super family Apoidea which includes bees and apoid wasps. They form an ecologically important group. Bees are basically phytophagous in diet as they feed majorly on nectar and pollen. Female bees in their adult stage go around foraging on the flowers for collecting food for their larval off springs. Bumble bees do not have social colony like honey bees, hence they do not gather and store much honey and pollen like latter. Bumble bees play a major role in pollination of a wide range of agricultural, horticultural and wild flora, especially on high altitudes.

Various special morphological features characterise bumble bees like the presence of white, black, yellow and orange bands. These bands are assemblage of soft hairs called pile or pubescence. Another important feature is the modification of hind leg of female into corbicula used for carrying pollen. Worldwide 250 species of bumble bees
${ }^{1}$ Shoolini University, School of Biological and Environmental Sciences, Bhajol, Solan-173 229, Himachal Pradesh, India.

${ }^{2}$ High Altitude Regional Centre, Zoological Survey of India, Solan173 229, Himachal Pradesh, India.

Corresponding Author: Priyanka Kumari, Shoolini University, School of Biological and Environmental Sciences, Bhajol, Solan173 229, Himachal Pradesh, India.

Email: priyanka.dadhwal.chandel@gmail.com

How to cite this article: Kumari, P., Sidhu, A.K. (2022). Taxonomic and Bio-geographical Studies of Three Bombus Species (Hymenoptera: Bombus) from North-West Himalaya with New Record from Trans Himalaya. Indian Journal of Animal Research. DOI: $10.18805 / I J A R . B-4549$.

Submitted: 28-05-2021 Accepted: 13-12-2021 Online: 07-01-2022

have been reported under the genus Bombus (Williams 1985, Pederson 1996). Linnaeus (1758), Smith (1852, 1861), Dalla Torre (1896), Bingham (1897), Richards (1928) are the major workers of Indian species. Saini et al. (2011, 2015) recorded 37 and 42 species respectively of bumble bees from North West Himalaya.

\section{MATERIALS AND METHODS}

The study was carried out in 2017-2019 at High Altitude Regional Centre, Z.S.I., Solan (H.P.) in North-West Himalaya and the areas covered were Kullu, Leh, Lahual and Spiti, Kinnaur, Keylong, Solan, Chail, Rampur ranging between 
Taxonomic and Bio-geographical Studies of Three Bombus Species (Hymenoptera: Bombus) from North-West Himalaya....

altitude of $1,021 \mathrm{~m}$ asl to $3,500 \mathrm{~m}$ asl. Foraging bees were collected with the sweeping nets. Bees usually forage in bright sunny days between 8 am to 4 pm in summers and 9 am to 3 pm during winters. The examples thus collected were kept in charged ethyl acetate collection bottle. These were then properly stretched to expose their taxonomically important parts. Stretched, identified and labelled specimens were then kept in sterilised insect boxes. Previously collected examples present in National Zoological Collections of ZSI, Solan were relaxed in phenol mixture, stretched and then studied. Adult examples were photographed with Nikon D7200. Adult specimens were given unique Identification registration numbers and digitised in proper format. These specimens are housed at H.A.R.C., ZSI, Solan. Floral associations of these bees were also noted and studied. Earlier records of distribution of these species in India and elsewhere in world were also studied. Material examined is provided giving details of the number of examples collected from each place in addition to their date of collection, sex, coordinates etc.

Male genitalic slides, sterna 7 and sterna 8 were dissected out and their slides were photographed with Olympus DC 7.4. Keys given by Williams (1991, 1998), William et al. (2008) and Saini et al. (2011, 2015) have been followed. Workable dichotomous keys were prepared for the identified species separately for females and males.

\section{RESULTS AND DISCUSSION Genus Bombus latreille}

Bombus Latreille 1802:437

Ashtonipsithyrus Frison 1927:69,

Allopsithyrus Popov 1931:136,

Metapsithyrus Popov 1931:135

Fernaldaepsithyrus Frison 1927:70

\section{Diagnosis}

Adults non-metallic, variable in size, robust; body hair or pile present that covers the entire body making it look fuzzy, body hairs present as bands of different colors like yellow and orange. Hind legs of female with pollen basket called corbicula surrounded by long hairs for carrying pollen; social with castes; morphological difference in different castes of species with male being larger in size than worker and queen being largest.

\section{Key to the speices of Bombus (Females)}

1. Hind tibiae bulged partly; mandibles apex blunt and converged with a basal and a apical tooth; antennomere 4 short; abdominal tergites 4-5 brick orange

\section{B. trifasciatus Smith}

Antennomere 4 longer than broad ....2

2. Pubescence of thoracic mesonotum with a broad black band between wing bases, whitish grey bands present anteriorly and posteriorly; wings infuscated.............. B. tunicatus Smith
Pubescence on thorax without the presence of black band on mesonotum; pubescence on abdominal tergites 4-5 orange red. B. simillimus Smith

\section{Key to the species of Bombus (Males)}

1. Malar space longer than basal breadth of mandible; anterior margin of labrum with notch in the middle...................................... trifasciatus Smith

Malar space shorter than basal breadth of mandible.........2 2. Weak band of sparse punctures along eye margin; unpunctured lateral ocelli; whole thorax covered with white pubescence; labrum anteriorly

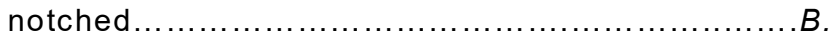
simillimus Smith

Thorax with a black band between wing bases on mesonotum; labrum concave on anterior side; lateral ocelli without punctures. B. tunicatus Smith

\section{Bombus trifasciatus Smith, 1852}

B. montivagus Smith, 1878: 168

B. secundus Dalla Torre, 1890: 139

B. ningpoensis Friese, 1909: 676

B. wilemani Cockerell, 1911: 100

B. haemorrhoidalis Friese, 1916: 108

B. mimeticus turneri Richards, 1931: 530

B. mimeticus insidiosus Richards, 1931: 531

B. malaise Skorikov, 1938: 2

Megabombus montivagus Tkalcu, 1968: 27

Diagnosis: Plate 1 (Fig a-f)

\section{Female}

Head and thorax of queenblack; pubescence on 1-3 abdominal tergites yellow; 4-5 abdominal tergites brick red. Workers are with 1-2 abdominal tergites yellow and 3-5 abdominal tergites brick red. Thick black pubescence on head except malar space; clypeus with punctures; head broad than long; mandibles thick with cutting edges, thorax and abdomen equally broad; pubescence on thorax black; wings dark brown; abdomen cordate at the apex. Dorsal surface of head with scattered punctures all over except ocellar depressions.

\section{Male}

Head and thorax with black pubescence except white lateral aspects in thorax; abdominal tergites 2-3 yellow, abdominal tergites 3-4 brick red; male smaller in size as compared to female; penis valve in genitalia short, flickered and toothed anteriorly; gonostylus broad and short, rectangular in shape with spines in internal proximities; strongly produced process present basally on the interior side; inner processes present in volsella, one of the hook is in apical direction and straight while the second one is basal, broad and hooked; penis valve head broad with pronounced teeth along inner edge. 


\section{Material examined}

Himachal Pradesh: Dist. Kullu, Shangarh, Sainj, 2ex, 14.vii.2017; Niharni, Sainj, 1ex, 16.vii.2017, Sainj Wild Life Sanctuary; Dist. Solan, Chail, 1ex, 1.vii.2018, 18 exs, 27.xi.2018; UT of Ladakh: Dist. Leh, Phey, 2 ex, 6.viii.2019.

\section{Distribution India}

Himachal Pradesh, Kashmir, Uttrakhand, Arunachal Pradesh, Sikkim, Manipur, West Bengal.

\section{Distribution elsewhere}

Myanmar, Thailand, South China, Taiwan, Pakistan, Nepal.

\section{Floral preferences}

Solanumn igrum; Chrysanthemum sp., Lupinius polyphullus, Brassica campestris; Dalhia verbalis; Cucurbitapepo; Tagetes sp.; Helianthus annuus (Fig 1).

\section{Remarks}

This species is common in lower altitudes of India and hence called Oriental species. This species has altitudinal distribution between 1500 to $2350 \mathrm{mts}$. above sea level and is common but has been observed in less numbers above $2350 \mathrm{mts}$ up to $3500 \mathrm{mts}$. The seasonal activity of these bees is very long as it emerges very early at the start of the

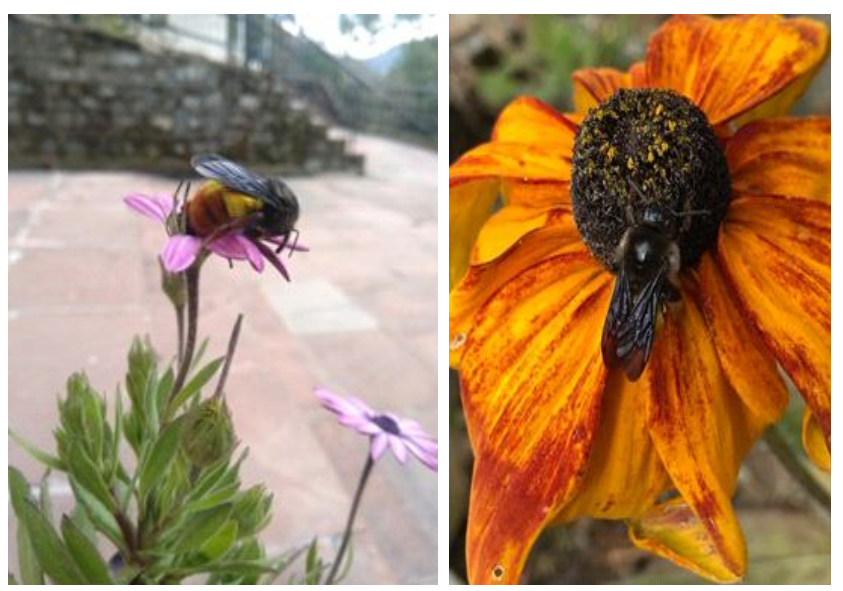

Fig 1: B. trifasciatus on Chrysanthemum spp.
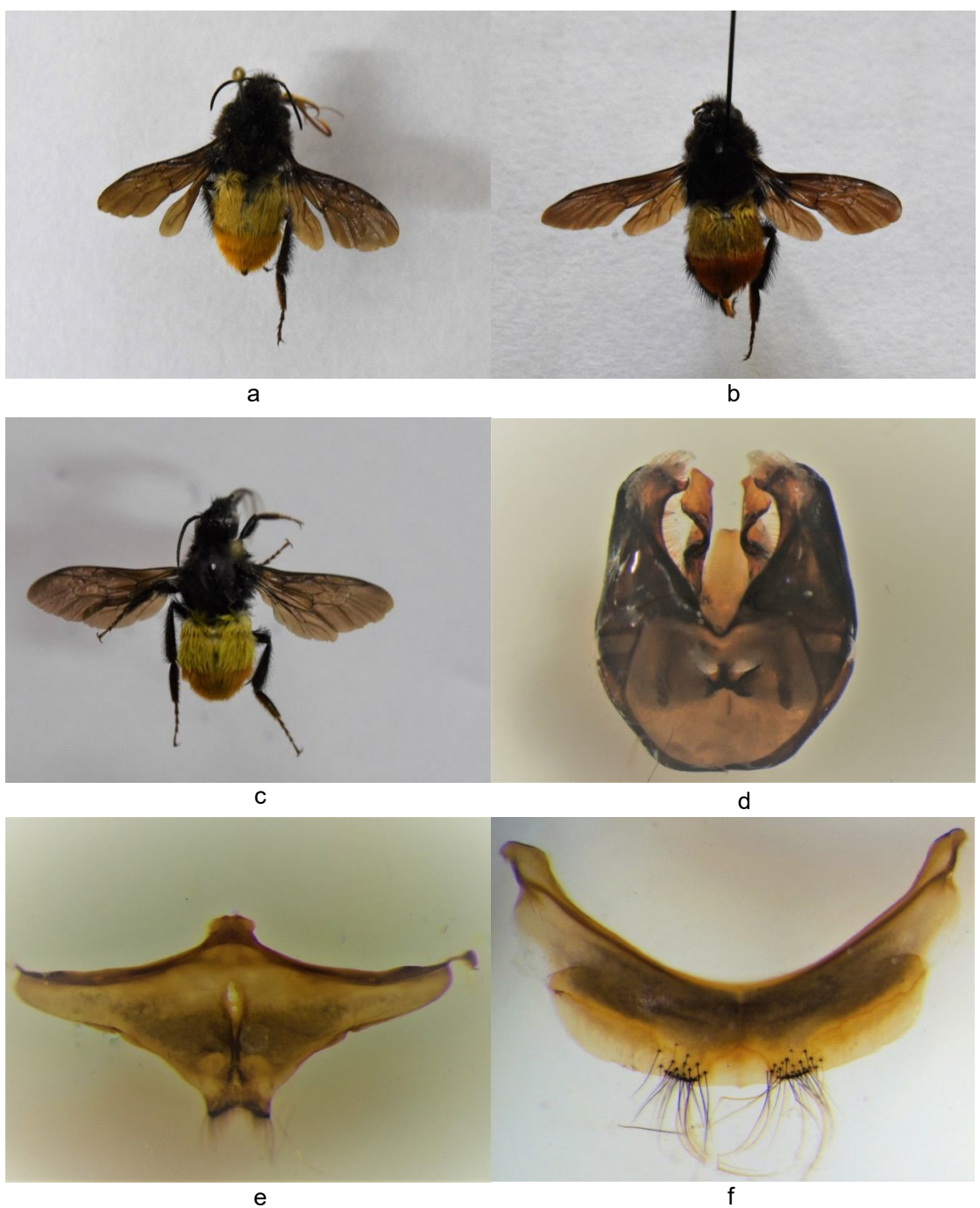

Plate 1: Bombus trifasciatus Smith a) Queen b) Worker c) Male d) Genitalia e) Sterna 7 f) Sterna 8. 
season. In the present studies this species has been recorded for the first time from Trans Himalaya. The specimens have been collected from Phey, Ladakh which is a high altitude cold desert in Trans Himalayan region of India. This region has harsh climatic conditions, very scanty precipitation leading to scarce vegetation in most parts of Ladakh.

\section{Bombus tunicatus Smith, 1852}

Bombus tunicatus Smith, 1852a: 43

Bombus vallestris Smith, 1878: 168

B. gilgitensis Cockerell, 1905: 223

B. terrestris Friese, 1909: 674

\section{Diagnosis: Plate 2 (Fig a-f)}

\section{Female}

Pubescence on head black; thorax with densely white pubescence with a black band in middle between wings; abdominal tergite 1 with white pubescence, 2-3 black and 4-5 with yellowish orange pubescence; all parts with thick pubescence; protuberant clypeus, margins bent inwards towards gena and supraclypeus, clypeus punctured with many scattered large punctures; meta tibiae and tarsi covered with scattered long black hair; posterior margin with convex shaped rounded distioanterior end.

\section{Male}

Head black; in thorax pronotum and metanotum with white pubescence, mesonotum with black band present between wings; abdominal tergite 1 white, 2-3 black and 4-5 brick orange; labrum covered with punctures; gonostylus with apical process on internal side; penis valve turned outside, flattened sickle shaped, strongly broadened dorsoventrally to form broad funnel; sclerotized volsella.

\section{Material examined}

Himachal Pradesh: Dist. Kinnaur, Chitkul, Sangla, 8ex, 10.x.2017; UT of Ladakh: Dist. Leh, Phey, 3 ex, 18.viii.2019.

\section{Distribution India}

Kashmir, Uttarakhand, Himachal Pradesh, Sikkim.
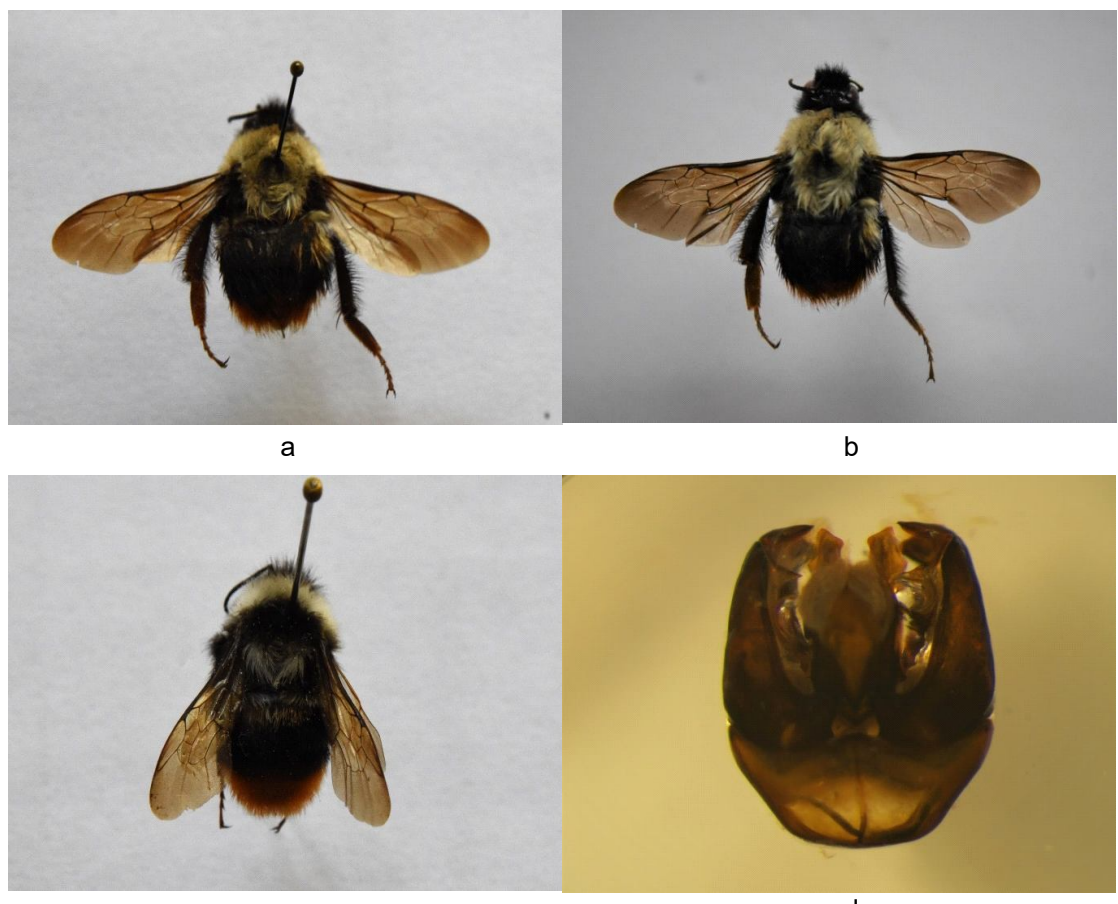

C

d
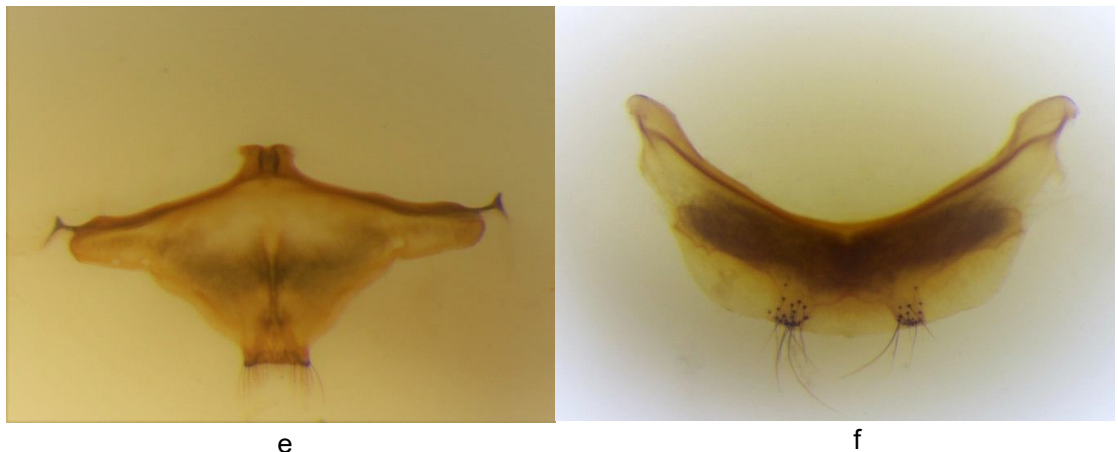

Plate 2: Bombus tunicatus Smith: a) Queen b) Worker c) Male d) Genitalia e) Sterna 7 f) Sterna 8. 


\section{Distribution elsewhere}

Nepal, Afghanistan, Pakistan, Nepal.

\section{Floral preference}

Artemisia majus; Allium cepa; Cichorium intybus; Zinnia elegans; Trifolium pratense; Digitalis lanata.

\section{Remarks}

B. tunicatusis a North West Himalayan species found mostly above the elevation of $2000 \mathrm{mts}$. above sea level but not below it.It has been reported between $2000 \mathrm{mts}$. to 5,500 mts. above sea level. The colour pattern of $B$. tunicatus is similar to $B$. simillimus except the absence of black band on mesonotum. It is more prevalent in coniferous forests.

\section{Bombus simillimus Smith, 1852}

B. similis Smith, 1854: 3

B. tonsus Skorikov, 1922: 160

B. terrestris Friese, 1931: 303

B. oculatus Richards, 1934: 87

Sibricombustonsus Skorikov, 1933: 248

\section{Diagnosis: Plate 3 (Fig a-f)}

\section{Female}

Head, thorax with black pubescence; abdominal tergites 13 black, 4-5 brick red; thorax is completely white in thorax; head covered with dense pubescence except malar space, clypeus, ocellar space; thick and dense pile present uniformly over thorax and abdomen in queen; pubescence very similar to $B$. tunicatus except the black band on mesonotum on thorax; corbicula or pollen basket present on hind tibiae fringed with long and scattered hairs; clypeus protuberant with scattered punctures; band of punctures scattered along eye margins; anterior area of lateral ocellus not punctured.

\section{Male}

Head covered with black pubescence; thorax and abdominal tergum 1 with white down; abdominal tergum 2 anteriorly with brown pubescence and posteriorly with white pubescence; abdominal tergum 3 with black down on anterior side and black down on posterior side; abdominal tergites 4-5 covered
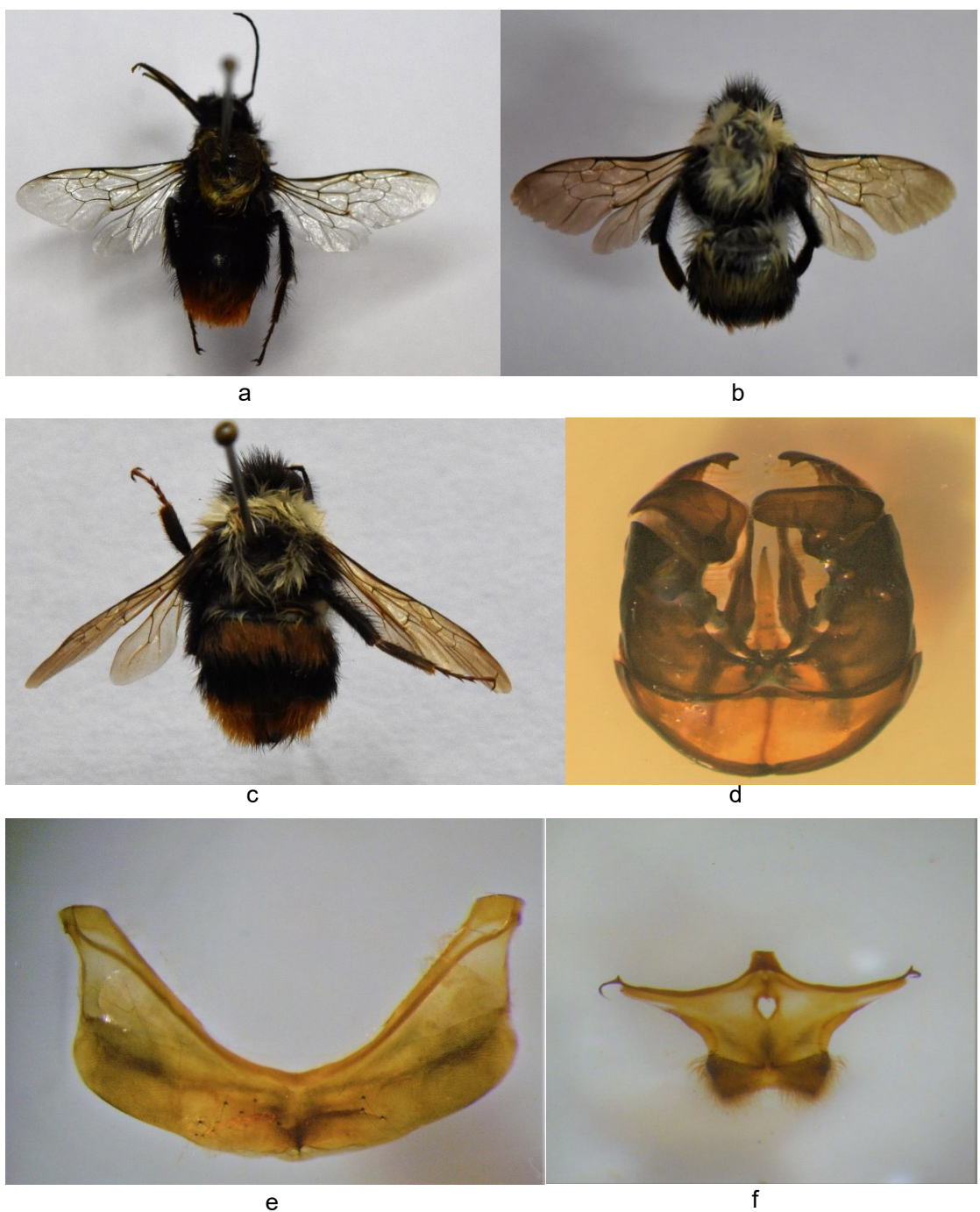

Plate 3: Bombus simillimus Smith: a) Queen b) Worker c) Male d) Genitalia e) Sterna 7 f) Sterna 8. 
with brick red pubescence; labrum notched in the middle on anterior end; lateral ocellus area not punctured; less number of punctures present along eye margin; gonostylus broad in the middle, gonobase broad anteriorly; sclerotized volsella, extending beyond gonostylus and toothed interiorly on apical front; penis valve toothed apically and singly with a sharp spine on the interior side.

\section{Material examined}

Himachal Pradesh: Dist. Lahaul and Spiti, Keylong, 4ex, 15.viii. 2018; Jhalam, 2 ex, 12.viii.2018; Keylong, 1ex, 11.viii. 2018.

\section{Distribution India}

Himachal Pradesh, Uttarakhand, Kashmir.

\section{Distribution elsewhere}

India and Pakistan.

\section{Floral preference}

Circium falcorneri, Impatiens balsamina, Althea rosea, Trifolium repens, Solanum nigrum, Rosa indica, Dahlia variabilis, Tagete spatula, Digitalis lanata.

\section{Remarks}

B. simillimus has been recorded between 1600-4000 mts. above sea level from North West Himalayas. It has never been recorded from north East Indian states. In Kashmir it is found on low lying coniferous forests. The colour pattern of queen is unique with whole body black coloured except tip of abdomen brick red.

\section{CONCLUSION}

Bumble bees are ecologically very important owing to the most important role of pollination played by them. They are polylectic bees (Westrich, 1996) i.e. they forage on a variety of flowers. They are better equipped to thrive in human oriented habitats hence they form an ideal group to study the after effects of urbanization. B. trifasciatus was observed to forage more commonly in the urban habitats of district Solan and Shimla as compared to $B$. tunicatus and $B$. simillimus which were found more commonly in the natural habitats of high altitudes. So we can say that $B$. trifasciatus has adapted itself to a certain extent in the human habitations as well as increased its habitat to Phey, Ladakh making it more successful in ecological setup.

\section{ACKNOWLEDGEMENT}

Authors acknowledges the support given by Chancellor, Shoolini University, Solan in addition to Director, ZSI, Kolkata for providing the financial and necessary laboratory facilities.

\section{REFERENCES}

Abhishag, M.M., Betsy, C.J. and Kumar, S.S. (2020). Comparative study on spermatological parameters and seminal plasma composition of labeo rohita strains from Tamil Nadu, India. Indian Journal of Animal Research. 54: 1229-1234.

Bingham, C.T. (1897). Hymenoptera Wasps and Bees, In: The Fauna of British India, [Blandford, W.T. (Ed.)], Including Ceylon and Burma. Taylor and Francis, London. 1: 579.

Dalla Torre. (1896). Catalogus hymenopterorum hucusque descriptorum systematicus et synonymicus. Volumen X: Apidae (Anthophila). Lipisae: Sumptibus Gulilmi Englemann.

Das, P. and Choudhury, R. (2020). Mitochondrial D-loop genetic diversity studies of rhinoceros unicornis in Assam, India. Indian Journal of Animal Research. 2021.(55): 6-10.

Linnaeus, C. (1758). Systema naturae per regna tria naturae, secundum classes, ordines, genera, species cum characteribus differentiis, synonymis, 1758, Holmiae: Laurentii Salvii.

Michener, C.D. (2000). The Bees of the World. The Johns Hopkins Universitiy Press, Baltimore, USA, 972.

Pederson, B.V. (1996). A phylogenetic analysis of cuckoo bumblebees (Psithyrus, Lepeletier) and bumblebees (Bombus Latrielle) inferred from sequences of the mitochondrial gene cytochrome oxidase, Molecular Phylogenetics and Evolution. 5: 289-297.

Richards, O.W. (1928). On a collection of humble-bees (Hymenoptera, Bombidae) made in Ladakh by Col. R. Meinertzhagen. Annals and Magazine of Natural History, Series 10(2): 333-336. http://dx.doi.org/10.1080/00222932808672888.

Saini, M.S., Raina, R.H. and Khan, Z.H. (2011). A checklist of Bumblebees (Hymenoptera: Apidae) from Indian Himalaya. Journal of Insect Science. 24: 326-52.

Smith, F. (1852). Description of some new and apparently undescribed species of hymenopterous insects from north China, collected by Robert Fortune, Transactions of the Entomological Society of London. 2: 33-45.

Smith, F. (1861). Description of new genera and species of exotic Hymenoptera. Journal of Entomology. 1: 146-155.

Tantia, M.S. and Vij, P.K. (2020). Population estimates of sheep and goat breeds of India, Indian Journal of Animal Research. 2000. (34): 60-63

Westrich, P. (1996). The Conservation of Bees. [A. Matheson, S. Buchmann, C.O. Toole, P. Westrich and I.H. Williams. (eds.)], London: Academic Press London.

Williams, P.H. (1985). A preliminary cladistics investigation of relatrionships among the bumblebees (Hymenoptera: Apidae) Systematic Entomology. 10: 239-255.

Williams, PH. (1991). The Bumble Bees of Kashmir Himalaya (Hymenoptera: Apidae: Bombinae), Bulletin of Natural History Museum London (Entomology). 60: 204.

Williams, P.H. (1998). An annotated checklist of bumblebees with an analysis of patterns of description (Hymenopetra: Apidae, Bombini), Bulletin of Natural History Museum London (Entomology), 67: 79-152.

Williams, P.H., Cameron, S.A., Hines, H.M., Cederberg, B. and Rasmont, P. (2008). A simplified subgeneric classification of the bumblebees (Genus Bombus), Apidologie. 39: 46-74. 